\title{
ANALISIS KEMANDIRIAN PANGAN ASAL TERNAK DALAM RANGKA MEMANTAPKAN KETAHANAN PANGAN DI KABUPATEN LAMPUNG BARAT
}

\author{
(Self Sufficiency Analysis Animal Food of to Strengthen Food Security \\ in West Lampung District)
}

Hasnul Abrar ${ }^{1}$, Ali Khomsan², dan Yayat Heryatno ${ }^{2}$

${ }^{1}$ Program Studi Manaj emen Ketahahan Pangan (MKP), Sekolah Pascasarjana, IPB.

${ }^{2}$ Departemen Gizi Masyarakat, Fakultas Ekologi Manusia (FEMA), IPB

Tel: 0251-8628304/ 8621258; Fax: 0251-8625846/8622276

\begin{abstract}
ABST RACT
The objectives of this research were to: (1) analyze animal food supply in West Lampung District; (2) analyze ideal animal food target and; (3) analyze animal food self sufficiency. This research was conducted by using retrospective and prospective design. The primary data was collected by conducting interview and giving questionnaire to the chosen sample. The secondary data was processed by using Food Balance Sheet (FBS) software to measure animal food supply including the number and the energy and protein content. Food self sufficiency was analyzed by production-supply and import-supply ratio. The average animal food supply in 2005, 2006, and 2007 is $21 \mathrm{~g} /$ capita/ day or $7.66 \mathrm{~kg} /$ capita/year, still lower than ideal supply $60 \mathrm{~g} /$ capita/ day or $21.90 \mathrm{~kg} /$ capita/ year. Protein supply of animal food is $2.86 \mathrm{~g} / \mathrm{capita} /$ day, lower than ideal supply $4.8 \mathrm{~g} /$ capita/ day.
\end{abstract}

Keywords: food supply, ideal food supplying projection, food self sufficiency, food security.

\section{PENDAHULUAN}

Pangan merupakan kebutuhan essensil dan komoditas paling strategis dalam kehidupan manusia, pemenuhan kebutuhan pangan merupakan hak azazi manusia. Ketahanan pangan berdasarkan Undang-undang Nomor 7 Tahun 1996 tentang Pangan adalah kondisi terpenuhinya pangan bagi rumah tangga yang tercermin dari tersedianya pangan yang cukup, baik jumlah maupun mutunya, aman, merata dan terjangkau. Untuk mencapai hal tersebut perlu diselenggarakan suatu sistem pangan yang memberikan perlindungan, baik pihak yang memproduksi maupun yang mengkonsumsi. Peraturan Pemerintah Nomor 68 Tahun 2002 tentang Ketahanan Pangan menegaskan bahwa untuk memenuhi konsumsi yang terus berkembang dari waktu ke waktu, upaya penyediaan pangan dilakukan dengan mengembangkan sistem produksi pangan yang berbasis pada sumber daya, kelembagaan, dan budaya lokal, mengembangkan efisiensi sistem usaha pangan, mengembangkan teknologi produksi pangan, mengembangkan sarana dan prasarana produksi pangan dan mempertahankan serta mengembangkan lahan produktif.

Di Kabupaten Lampung Barat terdapat beberapa jenis ternak yang dipelihara dan diusahakan oleh petani untuk dikembangkan dengan berbagai tujuan dan ini merupakan sum- ber daya pangan bidang peternakan. Masalahnya adalah apakah ketersediaan pangan yang ada dapat mencukupi kebutuhan gizi masyarakat, maka diperlukan suatu usaha untuk memahami situasi pangan disuatu daerah, dalam hal ini Kabupaten Lampung Barat. Pembangunan Ketahanan Pangan dilaksanakan untuk mewuj udkan kesejahteraan masyarakat khususnya menjamin ketersediaan pangan bagi seluruh penduduk dalam jumlah mutu, keragaman, kandungan gizi dan keamanannya serta terjangkau oleh daya beli masyarakat. Sejalan diberlakukannya Undang-undang Nomor 22 Tahun 1999 kemudian direvisi dengan Undangundang Nomor 32 Tahun 2004 tentang Pemerintahan Daerah, yang diwuj udkannya dengan desentralisasi kewenangan dari Pemerintah Pusat ke Pemerintah Daerah, terjadi perubahan yang mendasar pada berbagai aspek kehidupan berbangsa dan bernegara. Pembangunan pertanian, termasuk sektor peternakan memiliki peran yang sangat penting dalam meningkatkan ketahanan pangan, peningkatan pendapatan petani, kesempatan kerja, sumber pendapatan dan pengembangan perekonomian di daerah/regional dan nasional. Ketahanan pangan merupakan prasyarat dasar yang harus dimiliki oleh suatu daerah otonom, oleh karena itu kebijakan yang mengarah pada terciptanya ketahanan pangan harus mendapat prioritas utama. 
Salah satu arah kebijakan ketahanan pangan pada sisi ketersediaan adalah menjamin pengadaan pangan utama dari produksi dalam negeri. Berarti ketersediaan pangan didukung oleh ketersediaan pangan wilayah/ daerah. Dewan ketahanan Pangan melalui Kebijakan Umum Ketahanan Pangan tahun 2006 - 2009 menyatakan bahwa tujuan pembangunan ketahanan pangan adalah mempertahankan ketersediaan energi minimal 2200 $\mathrm{kkal} / \mathrm{kap} / \mathrm{hari}$ dan penyediaan protein minimal $57 \mathrm{gr} / \mathrm{kap} / \mathrm{hari}$. Salah satu pangan penyumbang gizi terbaik berasal dari protein hewani. Permasalahan dan tantangan dalam Pembangunan Ketahanan Pangan secara umum menyangkut pertambahan penduduk, semakin terbatasnya sumberdaya alam, masih terbatasnya sarana dan prasarana usaha di bidang pangan, semakin ketatnya persaingan pasar dengan produk impor, serta besarnya proporsi penduduk miskin. Teori Malthus menyatakan bahwa pertumbuhan penduduk mengikuti deret ukur, sedangkan pertumbuhan pangan mengikuti deret hitung.

Konsekuensi logis dari pernyataan tersebut apakah Sumber daya Pangan Asal ternak dan peningkatan ketersediaannya mampu mengimbangi pertumbuhan penduduk Kabupaten Lampung Barat yang pada tahun 2008 ini sudah berjumlah 420077 jiwa.

Tujuan penelitian ini adalah untuk menganalisis situasi penyediaan pangan, target penyediaan dan kemandirian pangan asal ternak dalam rangka memantapkan ketahanan pangan Kabupaten Lampung Barat. Tujuan Khusus: 1) Menganalisis ketersediaan pangan asal ternak Kabupaten Lampung Barat 2) Menganalisis proyeksi ketersediaan pangan ideal asal ternak Kabupaten Lampung Barat 3) Menganalisis kemandirian pangan asal ternak Kabupaten Lampung Barat 4) Merumuskan strategi kemandirian pangan asal ternak Kabupaten Lampung Barat.

\section{METODE PENELITIAN}

\section{Desain, Tempat, dan Waktu Penelitian}

Desain penelitian ini adalah retrospektif dan prospektif. Retrospektif dengan mengumpulkan data-data yang berkaitan dengan ketersediaan dan kemandirian pangan yang ada pada instansi terkait selama ini, kemudian diolah secara prospektif untuk keadaan ideal ke masa yang akan datang. Tempat penelitian di Kabupaten Lampung Barat .

\section{Jenis dan Cara Pengumpulan Data}

Jenis data yang dikumpulkan dalam penelitian ini meliputi data primer dan data sekunder. Data primer dikumpulkan melalui wawancara dan kuesioner dari responden dan narasumber terpilih dengan sengaja (purposive) baik pejabat maupun stakeholders yang berkaitan dengan penelitian, seperti: Bupati, Sekretaris Daerah, Asisten Ekonomi Pembangunan, Sekretaris dan Kepala Bidang di Bapeda, Ketua DPRD/Komisi B, Kepala Dinas Peternakan dan Kesehatan Hewan beserta Kepala-kepala Bidang, Kepala Badan Ketahanan Pangan dan Sekretaris Badan, Kepala Dinas Kelautan dan Perikanan, Kepala Dinas Pertanian dan Hortikultura, Kontak Tani Nelayan Andalan, dan mahasiswa magister manajemen Ketahanan Pangan IPB 2007.

Data sekunder diperoleh dari dinas/ instansi yang terkait dengan ketahanan pangan, seperti data: agroekologi, keadaan demografi, rencana tata ruang wilayah, ketersediaan pangan peternakan, strategi kebijakan ketahanan pangan.

\section{Pengolahan dan Analisis Data}

Data-data yang diperoleh baik data primer dan data sekunder di tabulasi dan diolah menggunakan komputer dengan program microsoft excel for windows. Beberapa metode yang diperlukan dalam analisis data adalah sebagai berikut :

\section{Ketersediaan Pangan}

a) Data ketersediaan pangan dihitung dari produksi masing-masing sumber daya pangan peternakan berdasarkan data NBM Kabupaten Lampung Barat tahun 2005 sampai dengan tahun 2007, di entri dari software aplikasi Neraca Bahan Makanan dan analisis situasi penyediaan pangan wilayah (Heryatno, 2006);

b) Analisis kuantitas ketersediaan pangan aktual mencakup: jumlah energi yang tersedia untuk konsumsi pangan asal ternak per kapita per penduduk, kontribusi energi kelompok pangan tersedia terhadap total energi, kontribusi masing-masing sumber daya pangan bidang peternakan;

c) Kontribusi energi masing-masing komoditas $=$ J umlah energi komoditas/jumlah energi total komoditas dikalikan $100 \%$

d) Ketersediaan protein pangan asal ternak juga di analisis dari NBM tersebut. 
Target dan Proyeksi Ketersediaan Pangan Asal Ternak ideal

a) Target penyediaan pangan dimaksudkan untuk mengetahui jumlah pangan asal ternak yang harus tersedia untuk dikonsumsi penduduk sesuai dengan kemampuan dan potensi wilayah dalam penyediaan pangan;

b) Proyeksi penyediaan pangan ideal adalah jumlah pangan asal ternak yang harus tersedia untuk dikonsumsi penduduk dalam satu tahun yang dinyatakan dalam satuan energi dan protein per kapita/hari dari setiap sumber daya pangan untuk mencapai pola pangan harapan ideal pada tahun tertentu.

$$
\mathrm{G}_{\mathrm{t}}=\mathrm{G}_{0}+\mathrm{n}\left(\mathrm{G}_{2015}-\mathrm{G}_{0}\right) / \mathrm{dt}
$$

Keterangan :

Gt = pangan tahun yang dicari

$\mathrm{G}_{0} \quad=$ pangan tahun awal

$\mathrm{n} \quad=$ selisih tahun yang dicari dengan tahun awal

$\mathrm{dt}=$ selisih tahun 2015 dengan tahun awal

$\mathrm{G}_{2015}=$ pangan tahun 2015 (ideal $=100$ )

Demikian juga dipergunakan rumus yang sama untuk menghitung ketersediaan energi (Kal/ kap/hari), ketersediaan protein (gr/ kap/ hari).

\section{Proyeksi Produksi Pangan}

Proyeksi Produksi Pangan menggambarkan proyeksi jumlah pangan yang harus diproduksi untuk memenuhi proyeksi ketersediaan yang telah ditetapkan sebelumnya. Asumsi yang digunakan: perubahan stok, ekspor dan pemakaian pangan pada tahun perhitungan sama dengan tahun dasar.

$$
\begin{aligned}
& \text { Prt }=K t+P S+E-I+(P+B+M=B M+T) \\
& \text { Keterangan : } \\
& P_{\mathrm{rt}} \quad=\text { proyeksi produksi pada tahun } \mathrm{t} \text { (tahun yang dicari) } \\
& \mathrm{K}_{\mathrm{t}}=\text { proyeksi ketersediaan untuk dikonsumsi (ton/ } \\
& \text { tahun) pada tahun } t \text { (tahun yang dicari) } \\
& \text { PS = perubahan stok pada tahun dasar } \\
& \mathrm{E} \quad=\text { penggunaan pangan untuk ekspor pada tahun dasar } \\
& \text { I = penggunaan untuk impor pada tahun dasar } \\
& \mathrm{P}=\text { penggunaan untuk pakan pada tahun dasar } \\
& B \quad=\text { penggunaan untuk bibit } \\
& \mathrm{M} \quad \text { = penggunaan untuk industri makanan tahun dasar } \\
& \mathrm{BM}^{\prime} \text { = penggunaan untuk industri non makanan tahun } \\
& \text { awal } \\
& \mathrm{T} \quad \text { = pangan yang tercecer pada tahun dasar }
\end{aligned}
$$

\section{Kemandirian Pangan Asal Ternak di Kabupa- ten Lampung Barat}

Dengan menganalisa potensi produksi, rasio impor, dengan menggunakan rumus:

1. Rasio produksi $=$ Produksi/ (Produksi + Impor - Ekspor) x $100 \%$
2. Rasio Impor $=$ Impor/ (Produksi + Impor Ekspor) x $10 \%$

\section{Merumuskan Strategi Kemandirian Pangan Asal Ternak Kabupaten Lampung Barat}

Dengan menggali hasil wawancara dengan stakeholders terpilih, dengan langkahlangkah sebagai berikut: a) Mendefinisikan persoalan dan merinci persoalan yang diinginkan b) Menyampaikan ringkasan hasil analisis ketersedian, target dan proyeksi pangan asal ternak dan analisis kemandiriannya c) Memintakan pendapat tentang analisis-analisis di atas d) Melakukan wawancara yang mendalam tentang strategi Kemandirian Pangan Asal Ternak dalam rangka memantapkan Ketahanan Pangan Kabupaten Lampung Barat e) Mengumpulkan dan mengelompokkan hasil wawancara f) Merumuskan strategi kemandirian pangan asal ternak Kabupaten Lampung Barat.

\section{HASIL DAN PEMBAHASAN}

\section{Ketersediaan Pangan Asal Ternak Aktual}

Dari hasil analisis, maka ketersediaan pangan asal ternak, dapat dilihat pada Tabel 1. Berdasar data pada tabel tersebut dapat kita lihat bahwa rata-rata ketersediaan energi pangan asal ternak masyarakat Kabupaten Lampung Barat baru berjumlah 40.80 kkal/ kap/hari, masih jauh apabila dibandingkan dengan Angka Kebutuhan Energi yang direkomendasikan, yaitu sebesar $105 \mathrm{kkal} / \mathrm{kap} / \mathrm{hari}$. Dengan cara yang sama dapat pula kita analisis dan diketahui bahwa ketersediaan protein pangan asal ternak rata-rata baru mencapai $2.86 \mathrm{gr} / \mathrm{kap} / \mathrm{hari}$, dibawah ketersediaan protein asal ternak yang ideal yaitu $4.8 \mathrm{gr} / \mathrm{kap} /$ hari. Demikian juga dengan jumlah pangan asal ternak tersebut baru mencapai $21 \mathrm{gr} / \mathrm{kap} /$ / hari atau $7.66 \mathrm{~kg} / \mathrm{kap} /$ tahun, keadaan ini dibawah ketersediaan normatif sejumlah 60 $\mathrm{gr} / \mathrm{kap} / \mathrm{hari}$ atau $21.90 \mathrm{~kg} / \mathrm{kap} / \mathrm{tahun}$.

\section{Proyeksi Ketersediaan Pangan Asal Ternak}

Untuk memenuhi kebutuhan masyarakat akan pangan asal ternak, maka proyeksi ketersediaannya harus dianalisis. Beberapa analisis dapat dilakukan seperti proyeksi ketersediaan energi (Kal/kap/hari), proyeksi ketersediaan protein (gr/ kap/hari), proyeksi jumlah (gr/ $\mathrm{kap} / \mathrm{hari}$, atau $\mathrm{kg} / \mathrm{kap} /$ tahun atau dalam satuan ton/tahun). Proyeksi ketersediaan energi untuk konsumsi, dapat dilihat pada Tabel 2. 
Tabel 1. Ketersediaan Energi Pangan Asal Ternak untuk Konsumsi Kabupaten Lampung Barat 20052007

\begin{tabular}{|c|c|c|c|c|c|}
\hline \multirow{2}{*}{ J enis Pangan } & \multicolumn{5}{|c|}{ Ketersedian energi untuk konsumsi (kkal/kapita/hari) } \\
\hline & 2005 & 2006 & 2007 & Rata-rata & Kontribusi (\%) \\
\hline 1. Daging sapi & 4.30 & 4.22 & 4.64 & 4.39 & 10.75 \\
\hline 2. Daging Kerbau & 0.06 & 0.08 & 0.11 & 0.08 & 0.20 \\
\hline 3. Daging kambing & 0.41 & 0.41 & 0.54 & 0.45 & 1.11 \\
\hline 4. Daging domba & 0.01 & 0.01 & 0.01 & 0.01 & 0.02 \\
\hline 5. Daging ayam buras & 8.46 & 8.28 & 8.02 & 8.25 & 20.23 \\
\hline 6. Daging ayam ras & 12.59 & 12.40 & 12.92 & 12.64 & 30.97 \\
\hline 7. Daging itik & 0.12 & 0.14 & 0.10 & 0.12 & 0.29 \\
\hline 8. Telur ayam buras & 3.16 & 3.30 & 1.97 & 2.81 & 6.89 \\
\hline 9. Telur ayam ras & 5.65 & 6.04 & 5.18 & 5.62 & 13.78 \\
\hline 10. Telur itik & 3.21 & 3.02 & 3.16 & 3.13 & 7.67 \\
\hline 11. Jeroan semua jenis & 1.70 & 1.67 & 1.77 & 1.71 & 4.20 \\
\hline 12. Susu & 138 & 1.65 & 1.72 & 1.58 & 3.88 \\
\hline J umlah & 41.05 & 41.22 & 40.14 & 40.80 & 100.00 \\
\hline
\end{tabular}

Tabel 2. Proyeksi Ketersediaan Energi untuk Konsumsi Pangan Asal Ternak

\begin{tabular}{|c|c|c|c|c|c|c|}
\hline \multirow{2}{*}{ J enis Pangan } & \multicolumn{6}{|c|}{ Proyeksi Ketersediaan energi untuk konsumsi (Kal/kap/hari) } \\
\hline & 2008 & 2009 & 2010 & 2011 & 2014 & 2015 \\
\hline 1. Daging sapi & 5.47 & 6.30 & 7.13 & 7.96 & 10.46 & 11.29 \\
\hline 2. Daging Kerbau & 0.12 & 0.13 & 0.15 & 0.16 & 0.19 & 0.21 \\
\hline 3. Daging kambing & 0.62 & 0.70 & 0.78 & 0.85 & 1.09 & 1.17 \\
\hline 4. Daging domba & 0.01 & 0.01 & 0.02 & 0.02 & 0.02 & 0.03 \\
\hline 5. Daging ayam buras & 9.67 & 11.33 & 12.98 & 14.63 & 19.59 & 21.24 \\
\hline 6. Daging ayam ras & 15.37 & 17.82 & 20.27 & 22.72 & 30.07 & 32.52 \\
\hline 7. Daging itik & 0.13 & 0.15 & 0.18 & 0.20 & 0.28 & 0.31 \\
\hline 8. Telur ayam buras & 2.63 & 3.29 & 3.94 & 4.60 & 6.57 & 7.23 \\
\hline 9. Telur ayam ras & 6.34 & 7.50 & 8.66 & 9.83 & 13.31 & 14.47 \\
\hline 10. Telur itik & 3.77 & 4.38 & 5.00 & 5.61 & 7.44 & 8.06 \\
\hline 11. Jeroan & 2.10 & 2.43 & 2.76 & 3.09 & 4.08 & 4.41 \\
\hline 12. Susu & 2.01 & 2.31 & 2.60 & 2.90 & 3.78 & 4.07 \\
\hline J umlah & 48.25 & 56.36 & 64.46 & 72.57 & 96.89 & 105.00 \\
\hline
\end{tabular}

Dari data yang tersaji pada tabel 2, dapat kita lihat proyeksi ketersediaan dari masing-masing jenis pangan asal ternak setiap tahun analisisnya. Pada tahun 2008 diperlukan energi pangan asal ternak sejumlah 48.25 $\mathrm{kkal} / \mathrm{kap} / \mathrm{hari}$, dan seterusnya. Dengan analisis yang sama, maka proyeksi ketersediaan protein pangan asal ternak tahun 2008 sejumlah $3.10 \mathrm{gr} / \mathrm{kap} / \mathrm{hari}$ dan seterusnya. Demikian juga dengan proyeksi ketersediaan pangan asal ternak untuk konsumsi dapat kita analisis dengan cara yang sama, dimana pada tahun 2008 diproyeksikan ketersediaan pangan asal ternak sejumlah 3924.43 ton, dan seterusnya.

\section{Kemandirian Pangan Asal Ternak}

Kemandirian pangan asal ternak, mengandung arti bahwa kebutuhan pangan asal ternak Kabupaten Lampung Barat harus dipenuhi secara mandiri dengan memberdayakan modal manusia, modal sosial dan ekonomi yang dimiliki petani, yang pada gilirannya harus berdampak kepada peningkatan kehidupan sosial dan ekonomi petani dan masyarakat lainnya. Selanjutnya kemandirian pangan diartikan bahwa kebutuhan pangan asal ternak dipenuhi minimal $90 \%$ dari dalam wilayah sendiri. Untuk mengkaji kemandirian pangan asal ternak Kabupaten Lampung Barat, dilakukan dengan melihat rasio produksi dibandingkan dengan ketersediaan pangan asal ternak Kabupaten Lampung Barat, atau melihat rasio impor terhadap ketersediaan pangan asal ternak Kabupaten Lampung Barat. Hasil Analisisnya dapat dilihat pada Tabel 3.

Dari tabel 3 maka dapat diketahui bahwa jenis pangan susu, daging ayam ras, daging kerbau dan telur ayam ras termasuk pangan asal ternak yang belum mandiri, sedangkan daging sapi, daging kambing, daging domba, daging ayam buras, daging itik, telur ayam buras, telur itik dan jeroan semua jenis termasuk pangan yang sudah mandiri dan mampu menyediakan pangan untuk konsumsi penduduk dari dalam wilayah Kabupaten Lampung Barat sendiri.

Dari tabel 5 di atas maka dapat diketahui bahwa jenis pangan susu, daging ayam ras, daging kerbau dan telur ayam ras termasuk pangan asal ternak yang belum mandiri, sedangkan daging sapi, daging kambing, daging domba, daging ayam buras, daging itik, telur ayam buras, telur itik dan jeroan semua jenis termasuk pangan yang sudah mandiri dan 
mampu menyediakan pangan untuk konsumsi penduduk dari dalam wilayah Kabupaten Lampung Barat sendiri.

\section{Strategi Memantapkan Kemandirian Pangan Asal Ternak Kabupaten Lampung Barat}

Untuk merumuskan strategi kemandirian pangan asal ternak di Kabupaten Lampung Barat, maka dilakukan analisis gabungan antara penyediaan pangan asal ternak yang aktual berdasarkan laju pertumbuhan produksinya, dibandingkan dengan proyeksi produksi berdasarkan keadaan ideal yang diinginkan, sehingga hasil analisisnya berupa Gap proyeksi penyediaan. Selanjutnya berdasarkan gap proyeksi produksi yang ada kita konversikan dalam persentase, dengan membagi gap yang ada dengan keadaan yang ideal. Selanjutnya proyeksi produksi dapat kita hitung dan analisis per tahunnya. Hasil analisis gap proyeksi produksi ideal dan analisis proyeksi produksi aktual (berdasar laju pertumbuhan produksi), dapat dilihat pada Tabel 4, di bawah ini.

Dari tabel 4 di atas dapat kita analisis bahwa gap proyeksi produksi daging sapi, daging ayam buras, daging ayam ras, daging itik, telur ayam buras, telur itik dan susu semakin berkurang dari produksi yang ideal. Hal ini berarti jenis pangan tersebut perlu mendapat perhatian untuk peningkatannya. Sedangkan daging kerbau, daging kambing dan domba gap nya semakin baik, yang berarti strategi yang ada sudah cukup baik dan memadai. Untuk mendapatkan strategi teknis yang terarah, maka peningkatan laju proyeksi produksi harus dihitung dan dianalisis dengan membandingkan gap produksi dengan proyeksi produksi idealnya, seperti pada Tabel 5.

Tabel 3. Rasio Produksi dan Rasio Impor terhadap Penyediaan Pangan Asal Ternak Kabupaten Lampung Barat tahun 2005-2007

\begin{tabular}{|c|c|c|c|c|c|c|}
\hline \multirow[t]{2}{*}{ J enis Pangan } & \multicolumn{3}{|c|}{$\begin{array}{c}\text { Rasio produksi terhadap penyediaan dalam } \\
\text { kabupaten (\%) }\end{array}$} & \multicolumn{3}{|c|}{$\begin{array}{l}\text { Rasio impor terhadap penyediaan } \\
\text { dalam kabupaten (\%) }\end{array}$} \\
\hline & 2005 & 2006 & 2007 & 2005 & 2006 & 2007 \\
\hline 1. Daging sapi & 97.13 & 97.17 & 97.19 & 2.87 & 2.83 & 2.81 \\
\hline 2. Daging Kerbau & 91.67 & 86.67 & 80.95 & 8.33 & 13.33 & 19.05 \\
\hline 3. Daging kambing & 105.00 & 10233 & 96.36 & -5.00 & -2.33 & 3.64 \\
\hline 4. Daging domba & 108.33 & 100.00 & 110.00 & -8.33 & 0.00 & -10.00 \\
\hline 5. Daging ayam buras & 100.00 & 100.00 & 100.00 & 0.00 & 0.00 & 0.00 \\
\hline 6. Daging ayam ras & 1.59 & 1.56 & 1.18 & 98.41 & 98.44 & 98.82 \\
\hline 7. Daging itik & 100.00 & 100.00 & 100.00 & 0.00 & 0.00 & 0.00 \\
\hline 8. Telur ayam buras & 100.00 & 100.00 & 100.00 & 0.00 & 0.00 & 0.00 \\
\hline 9. Telur ayam ras & 6.46 & 5.85 & 5.15 & 93.54 & 94.15 & 94.85 \\
\hline 10. Telur itik & 100.00 & 100.00 & 100.00 & 0.00 & 0.00 & 0.00 \\
\hline 11. Jeroan & 100.00 & 100.00 & 100.00 & 0.00 & 0.00 & 0.00 \\
\hline 12. Susu & 0.00 & 0.99 & 0.93 & 100.00 & 99.01 & 99.07 \\
\hline
\end{tabular}

Sumber: NBM Kabupaten Lampung Barat 2005-2007

Tabel 4. Gap Proyeksi Produksi Ideal dan Aktual Pangan Asal Ternak

\begin{tabular}{lrrrrr}
\hline \multicolumn{1}{c}{ J enis Pangan } & \multicolumn{5}{c}{ Gap Proyeksi Produksi (ton/tahun) } \\
\cline { 2 - 6 } & $\mathbf{2 0 0 8}$ & $\mathbf{2 0 0 9}$ & $\mathbf{2 0 1 0}$ & $\mathbf{2 0 1 4}$ & $\mathbf{2 0 1 5}$ \\
\hline 1. Daging sapi & 64.04 & 10.82 & -43.21 & -263.76 & -318.78 \\
2. Daging Kerbau & 13.95 & 19.43 & 27.15 & 95.14 & 127.02 \\
3. Daging kambing & 21.42 & 21.69 & 23.01 & 43.03 & 53.00 \\
4. Daging domba & 9.45 & 10.00 & 10.60 & 13.46 & 14.32 \\
5. Daging ayam buras & 189.60 & 72.71 & -48.10 & -569.92 & -709.50 \\
6. Daging ayam ras & -133.12 & -305.69 & -484.09 & -1254.74 & -1460.90 \\
7. Daging itik & 1.97 & 0.18 & -1.67 & -9.61 & -11.72 \\
8. Telur ayam buras & -123.28 & -225.54 & -323.98 & -703.94 & -799.13 \\
9. Telur ayam ras & -372.15 & -590.26 & -815.53 & -1787.60 & -2047.53 \\
10. Telur itik & -104.08 & -182.21 & -263.10 & -613.71 & -707.71 \\
11. Susu & -162.06 & -274.68 & -391.16 & -894.47 & -1029.09 \\
\hline
\end{tabular}


Tabel 5. Persentase peningkatan proyeksi produksi pangan asal ternak (\%)

\begin{tabular}{lcccc}
\hline \multicolumn{1}{c}{ J enis Pangan } & \multicolumn{2}{c}{$\begin{array}{c}\text { Analsis gap dan proyeksi produksi } \\
\text { ideal tahun } \mathbf{2 0 1 5} \text { (ton) }\end{array}$} & $\begin{array}{c}\text { Persentase gap } \\
\text { (\%) }\end{array}$ & $\begin{array}{c}\text { Laju peningkan produksi } \\
\text { (\%) }\end{array}$ \\
\cline { 2 - 5 } & gap & Ideal & Gap/ideal & Persentase/ tahun \\
\hline 1. Daging sapi & -318.78 & 1086.41 & 29.34 & 4.19 \\
2. Daging Kerbau & 127.02 & 48.79 & 260.34 & $37.19^{*}$ \\
3. Daging kambing & 53.00 & 154.26 & 34.35 & $4.91^{*}$ \\
4. Daging domba & 14.32 & 10.37 & 138.09 & $19.72^{*}$ \\
5. Daging ayam buras & -709.50 & 1412.45 & 50.23 & 7.17 \\
6. Daging ayam ras & -1460.90 & 1467.92 & 99.52 & 14.12 \\
7. Daging itik & -11.72 & 20.70 & 56.61 & 8.08 \\
8. Telur ayam buras & -799.13 & 819.64 & 97.49 & 13.92 \\
9. Telur ayam ras & -2047.53 & 2059.50 & 99.41 & 14.20 \\
10. Telur itik & -707.71 & 1066.51 & 66.35 & 9.47 \\
11. Susu & -1029.09 & 1038.57 & 99.08 & 14.15 \\
\hline
\end{tabular}

Keterangan : * jenis pangan dengan laju petumbuhan produksi melebihi ketersediaan idea, sehingga diharapkan mampu mensubsitusi pangan asal ternak lainnya.

Dari tabel 5 yang tersaji, maka jenis pangan daging sapi perlu ditingkatkan produksinya sejumlah $4.9 \%$ tahun, daging ayam buras $7.17 \%$ tahun, daging ayam ras $14.12 \%$ tahun, daging itik $8.08 \%$ tahun, telur ayam buras $13.92 \%$ tahun, telur ayam ras $14.20 \%$ dahun, telur itik $9.47 \%$ tahun dan susu $14.15 \%$ tahun. Peningkatan produksi yang direkomendasikan harus juga diikuti dengan strategi: meningkatkan permodalan dan taraf hidup petani ternak, peningkatan SDM, perbaikan sarana dan prasarana, pengembangan komoditas berdasarkan keunggulan wilayah, penerapan teknologi, penyuluhan gizi dan pemberantasan dan pencegahan penyakit ternak.

\section{KESIMPULAN}

Ketersediaan pangan asal ternak aktual rata-rata dari analisis dan koreksi NBM 2005, 2006 dan NBM 2007 sebanyak 21 gr/ kapita/ hari atau $7.66 \mathrm{~kg} / \mathrm{kapita} /$ tahun. Ketersediaan ini masih di bawah ketersediaan ideal yang direkomendasikan sebanyak $60 \mathrm{gr} /$ kapita sehari atau $21.90 \mathrm{~kg} / \mathrm{kapita} /$ tahun. Ketersediaan protein asal ternak aktual sebanyak $2.86 \mathrm{gr} /$ kapita/hari. Ketersediaan ini masih di bawah ketersediaan ideal yang dianjurkan sebanyak $4.8 \mathrm{gr} / \mathrm{kapita} / \mathrm{hari}$.

Proyeksi ketersediaan pangan asal ternak untuk memenuhi kebutuhan pangan asal ternak masyarakat Kabupaten Lampung Barat tahun 2008 sebanyak 25.59 gr/kapita/hari, tahun 2009 sebanyak 30.51 gr/kapita/hari, tahun 2010 sebanyak 35.43 gr/kapita/hari, tahun 2011 sebanyak 40.33 gr/kapita/hari, tahun 2014 sebanyak 55.08 gr/kapita/hari, untuk menuju kepada penyediaan ideal tahun 2015 sebanyak $60 \mathrm{gr} / \mathrm{kapita} / \mathrm{hari}$. Untuk memenuhi kebutuhan pangan masyarakat Kabu- paten Lampung Barat akan pangan asal ternak, maka produksinya diproyeksikan pada tahun 2008 sebanyak 4382.00 ton, tahun 2009 sebanyak 5313.40 ton, tahun 2010 sebanyak 6 278.82 ton, tahun 2011 sebanyak 7270.03 ton, tahun 2014 sebanyak 10435.95 ton dan tahun 2015 sebanyak 11560.83 ton.

Kemandirian pangan Kabupaten Lampung Barat dapat dilihat dari besaran ketergantungan impor terhadap penyediaan pangan asal ternak 2005 - 2007. J enis pangan susu, daging ayam ras, daging kerbau dan telur ayam ras termasuk pangan asal ternak yang belum mandiri. Berdasarkan rasio impor terhadap penyediaan dalam Kabupaten Lampung Barat, maka daging sapi, daging kambing, daging domba, daging ayam buras, daging itik, telur ayam buras, telur itik dan jeroaan semua jenis termasuk pangan asal ternak yang mampu menyediakan pangan untuk konsumsi penduduk dari dalam wilayah sendiri.

Strategi untuk memantapkan dan meningkatkan kemandirian pangan asal ternak dilakukan: meningkatkan populasi, produksi dan produktifitas ternak, meningkatkan permodalan dan pendapatan peternak dan masyarakat, meningkatkan SDM bidang peternakan, mengembangkan kawasan peternakan berbasis komoditas dan keunggulan wilayah serta mencegah, mengobati dan memberantas penyakit hewan berbahaya.

\section{DAFTAR PUSTAKA}

[DKP-Deptan] Dewan Ketahanan PanganDepartemen Pertanian. 2005. Neraca Bahan Makanan Indonesia. Jakarta; BKP-Deptan. 
J urnal Gizi dan Pangan, November 2008 3(3): 205 - 211

Heryatno Y. 2006. Program Analisis Pola Pangan Harapan Neraca Bahan Makanan. Kerjasama Pusat Pengembangan Ketersediaan Pangan Badan Bimas Ketahanan Pangan Departemen Pertanian dengan Departemen Gizi Masyarakat dan Sumberdaya Keluarga, Fakultas Pertanian, IPB, Bogor.
[PP No.68/2002] Peraturan Pemerintah Republik Indonesia Nomor 68 Tahun 2002 tentang Ketahanan Pangan; J akarta.

[UU No. 7/1996]. Undang-undang Nomor 7 Tahun 1996 tentang Pangan. 